\title{
GREENHOUSE GAS EMISSIONS DUE TO THE CONSTRUCTION OF RESIDENTIAL BUILDINGS IN MORADABAD, INDIA
}

\author{
TiRTH, V. ${ }^{*}-$ Algarni, $S .{ }^{1}-$ AgARWAL, ${ }^{2}{ }^{2}-$ SAXENA, A. ${ }^{2}$ \\ ${ }^{I}$ Mechanical Engineering Department, College of Engineering, King Khalid University, \\ Guraiger, Abha-61411, Asir, Kingdom of Saudi Arabia \\ (phone: +966-59-211-8330; fax: +966-17-241-8152) \\ ${ }^{2}$ Mechanical Engineering Department, Moradabad Institute of Technology, Moradabad \\ 244001, India \\ *Corresponding author \\ e-mail:v.tirth@gmail.com,vtirth@kku.edu.sa \\ (Received 27 $7^{\text {th }}$ Apr 2019; accepted 12 $2^{\text {th }}$ Jul 2019)
}

\begin{abstract}
In this study, greenhouse gas emitted during the construction stages of three residential buildings with land areas of $204 \mathrm{~m}^{2}, 150 \mathrm{~m}^{2}$ and $120 \mathrm{~m}^{2}$ in Moradabad city $\left(8.866790{ }^{\circ} \mathrm{N}, 78.755921{ }^{\circ} \mathrm{E}\right)$ in northern India have been estimated and analyzed. Post design, the construction of a residential building involves five stages viz. design, production of building materials, mobilization of materials, building construction, and disposal of construction waste. Mathematical equations have been developed to calculate the greenhouse gas emissions in all the five stages as well as to estimate the aggregate emissions. Emissions from human-related activities like on-site cooking and water consumption have been included. The results indicate that the production of building materials is responsible for $74 \%$ of the total emissions. Steel, concrete, bricks, and cement are consumed in a large volume during the construction and have an environmental impact. Average Greenhouse Gas emissions of the three residential buildings were estimated to be about $0.784 \mathrm{tCO}_{2} \mathrm{e} / \mathrm{m}^{2}$. Selecting the alternative building materials with low greenhouse gas emissions and incorporating a major renewable energy source are foremost priorities for future construction projects.
\end{abstract}

Keywords: construction stages, building materials, human activities, environment, global warming potential, carbon footprint

Abbreviations: Greenhouse Gas: GHG, Gross Domestic Product: GDP, Global Warming Potential: GWP, Carbon Foot Print: CFP, Liquefied Petroleum Gas: LPG

\section{Introduction}

Energy systems are essential for human activities and play a crucial part in the economic growth of the nation. On the other hand, they have ecological implications, including the release of greenhouse gases (GHG) into the atmosphere resulting in the degradation of the environment. The growth of energy systems is difficult to forecast as they are governed by several dynamic factors like population growth, technological development, and socio-economic factors. In the year 2012, the worldwide $\mathrm{CO}_{2}$ emissions due to energy use touched a remarkable high level of $31.6 \mathrm{Gt}$ (Hong et al., 2015), stagnated in 2014 (32.2 Gt), in spite of about 3\% economic growth of the world. It was the first of such observations in the last four decades in which stagnation in emissions was not related to the economic slowdown (International Energy Agency, 2015).

The economic development of the countries is mainly related to the development of infrastructure for which construction activities are key consumers of resources and energy. Therefore, for a sustainable society, it becomes important to engross the construction industries (Asif et al., 2007). The building construction has an effect on numerous secondary commercial activities due to the consumption of a wide range of 
materials, manufactured in diversified small and big industries (Suzuki et al., 1995). Typical building construction requires about $40 \%$ of the gravel-stone-sand, $25 \%$ wood and, 16\% water per annum globally (Arena et al., 2003). The Statics times (2015), reported that the construction industry occupied $8.09 \%$ of Gross Domestic Product (GDP) in 2014 with its production amounting to 928,418 crore Indian rupees. According to Nation Master Statistic (2013), more than 33\% of the global emissions and the energy consumption were due to the building construction industry in developing as well as the developed nations. This resulted in the diminution of non-renewable energy assets, obliteration of landscapes, leading to the generation of environmental issues, linked indirectly or directly to the community working in this sector. The total embodied energy involved in building construction is proportionate to the quantity of the building material consumed during the different stages of construction and to the embodied energy of materials (Dimoudi et al., 2008). Therefore, it is imperative to consider the impact on the environment and aim to mitigate the effects of building construction on it.

Reducing GHG emissions from construction industries may fetch numerous advantages to society as well as the economy. The construction, maintenance, and renovation activities contribute between 10-40\% of the GDP of countries', and about $10 \%$ of employment (UNEP, 2009). The meticulous design of the buildings and proper planning of the construction activities may help in the mitigation of GHG and, at the same time, can rouse the new job opportunities in India and other developing countries. It can also help in social development by providing improved accommodations, clean water and, energy to the community. Top management and policymakers should grab the business prospects due to the environmental crisis, to take a lead in sustainable development. To adopt any mitigation policy, it is, therefore significant to estimate the GHG emissions caused due to different construction stages in developing countries such as India.

\section{GHG emissions}

The GHG such as carbon dioxide, ozone, methane, water vapor, and nitrous oxide have a tendency to captivate and release radiations in the thermal infrared range, causing the greenhouse effect, which is a primary reason for global warming.

Due to human activities, the $\mathrm{CO}_{2}$ level in the atmosphere has increased to $400 \mathrm{ppm}$ compared to $280 \mathrm{ppm}$ in 1750, a rise of $40 \%$ (Blasing et al., 2014). The main reasons for the increase in anthropogenic carbon emissions are due to the use of fuels namely; oil, gas, coal, wood, etc. and rapid deforestation.

It is projected that with the current rate of increase in carbon emissions, the atmospheric temperature can rise more than historic limits within 30 years. The rise in the temperature of the earth's atmosphere will not only result in rising sea level, but it will cause severe threats to the ecological balance and survival of biodiversity across the globe (Mora et al., 2013).

\section{Indirect and direct emissions}

The present work includes both indirect and direct GHG emissions, as well as the emissions during building construction. The construction activities may not directly consume large quantum of energy but their indirect energy footprint is huge due to the consumption of materials processed through high energy-intensive processing. A few examples of high-energy intensive materials used in the construction industry are steel, bricks, aluminum, cement, glass, etc. In this study, the direct emissions during 
construction stages refer to those due to the direct energy use at the site and the indirect emissions are due to the energy footprint and hence add to the carbon emissions of the materials used in building construction. It is expected that this study shall give a comprehensive understanding of emissions from building construction stages in northern India and help in determining the solution for the mitigation of carbon emissions in a phased manner.

\section{Review of literature}

In recent decades, varieties of studies have been carried out to analyze the carbon and energy footprints of building and construction activities. The studies carried out are different in scope and methodology. The building life cycle activities were also analyzed. Some related research findings are discussed in this section.

Onat et al. (2014) addressed the rapidly growing emission tendency in the residential buildings in the United States in an attempt to minimize the emissions. The authors concluded that promoting the construction of green buildings is insufficient to curb the emissions unless the existing buildings are retrofitted. Therefore, it becomes necessary to implement a strict green building policy, which should include the new as well as old buildings. Chou and Yeh (2015) proposed a method to augment the $\mathrm{CO}_{2}$ emissions and their implications on the environment while assessing the life cycle of the buildings. This methodology may be useful in the valuation of major environmental risks for the life cycle of buildings and the selection of a suitable method for construction. Lin et al. (2015) studied the emissions in residential and commercial buildings in China and evaluated the energy-related economic factors. The results indicate that emissions related to energy during building construction are growing briskly and are expected to shoot further in China's eastern regions, particularly in South Asia due to significant migration of people to the urban areas from rural regions.

Akten and Akyol (2018), in their study on Izmir province in Turkey, suggested that the ecological footprint of many countries has exceeded their biocapacity. The human activities and their consumption habits have resulted in an ecological deficit, and the problem is increasing with every passing day.

Doğan (2018) in his detailed study on Eurasian regions and Turkey over a period of 13 years emphasized the connection between global warming and $\mathrm{CO}_{2}$ concentration. He found that awareness among the population plays a major role in the success of the mitigation policies.

Yang et al. (2018) observed $\mathrm{CO}_{2}$ concentration around China and raised questions on assumptions of uniform $\mathrm{CO}_{2}$ level in the atmospheres.

Zheng et al. (2018) in a study on urbanization in China, recommended different policies for reducing carbon emissions for different levels of urbanization.

Marsono et al. (2015) proposed a methodology to reduce the effect of $\mathrm{CO}_{2}$ emission for buildings as well as to improve their structural stability by encouraging the Malaysian construction industry to increase the use of wood in their building schemes. This methodology can help decision-makers to select the most flexible scheme for Malaysian housing. Lai (2015) conducted a study to explore the carbon footprints (CFP) of three typical hotels in Hong-Kong and found that electricity consumption was the main source of carbon emission. Sharma et al. (2012) assessed a three-story building in the northern region of India. They concluded that the reinforced cement concrete (RCC) framework and steel are the biggest contributors in GHG emissions. Devi and 
Palaniappan (2014) presented a life cycle analysis of energy in a residential apartment located in the southern region of India. The effect of the service life of the building and monthly electricity consumption on the energy used in construction was predicted using sensitivity analysis. Wang et al. (2015) calculated the carbon emissions from the highway construction activities namely road construction, bridge construction and making the tunnels as 5229,35547 , and $42302 \mathrm{kgCO}_{2 \mathrm{e}} / \mathrm{m}$ respectively. They suggested a simple mathematical model to assess the $\mathrm{CO}_{2}$ emissions from road construction activities. A similar model to assess the emissions from the building construction will be very useful.

Li et al. (2019) assessed the GHG emission in China in different phases of building construction. Their work was focused on the $\mathrm{CO}_{2 \mathrm{e}}$ of building materials procured from urban, national, and global markets. Ceramics and basic construction material were obtained from the urban market, paints and chemicals were obtained from the national market, and metals and petroleum were the materials, which were derived from global sales. The contribution of urban, national, and global materials was estimated to be $68.78 \%, 24.41 \%$, and $6.8 \%$ respectively.

In a study on a Norwegian office building, Moschetti et al. (2019) explored the pathways towards zero-emission buildings. To achieve their objective, they emphasized on alternative design solutions and use of solar energy and building materials with low global warming potential (GWP). The use of solar energy reduced emissions by $30 \%$.

Buildings and construction activities are responsible for the diminution of natural resources and impact the environment and so, this sector has attracted the environmentalists for assessment of emissions and attempts to suggest methods for controlling the impact on environment and depletion of natural resources. Hossain and Thomas (2019) studied the adopted resource recovery principle to reduce waste, increase the efficiency of waste disposal and resource-efficient constructions. They suggested a few sustainable strategies for waste treatments. Some of these strategies included recycling and recovery of secondary materials like timber waste, mortar, etc.

In a study on the building life-cycle carbon emissions in China (Can et al., 2019) reported that the production of building material is a major contributor to the emissions, followed by the construction activities. The study also suggested that the variables such as GDP, income, urbanization, price and overall economy directly affect the emissions by influencing the surge in the construction industry. The effective methods to curb the emissions from building and construction activities may be focused on implementing cleaner technology during the production stages of construction materials and the building design.

Wong et al. (2019) in a study in Australia suggested that the estimation of the embodied emission due to stages of building construction shall be made a mandatory practice. The construction industry has misnomer about carbon accounting and sees it as a threat to increase its cost and efficiency. The regulations of the government to promote designs of low CFP buildings and construction activities may have an immediate positive impact on carbon emissions.

From the literature review it may be extracted that though the effect of building construction materials on the environment and $\mathrm{CO}_{2}$ emissions have been investigated and analyzed in different regions for different sizes and utilities of the buildings, it is apparent that construction-related human activities like on-site cooking, water consumption has been ignored in the published research. Without the incorporation of human activities, the assessment and GHG emissions from the construction activities 
and their analysis is incomplete. Human activities should be given special consideration by the researchers as they affect the GHG emission during the construction phase. Apart from the earlier research work, the present work includes the carbon emissions due to various human actions based on comprehensive process data and the case studies selected in India. The previous research has given limited attention to the buildings of the size and classification identified for the present analysis. The size and carpet areas of the buildings identified for the study are those, which are expected to develop the most in near future and so, with about one-sixth of the world population and being a fast developing country, the study made in the present manuscript is a relevant one.

\section{Materials and methods}

\section{Methodologies}

Scope of study

The study encompasses the GHG emissions during the stages of construction including several construction activities in the residential buildings, identified and closely studied from the start of construction to its completion. The inherited associated emissions from the materials, GHG emissions from the fuel burned to transport the building materials to the construction site and to transport the construction waste, emissions due to human activities, direct emissions due to electric power consumption at the site and, emissions due to the processing of water and sewage are included in the study.

\section{System boundaries}

System boundaries demonstrate the activities included in the analysis. Several aspects influence the GHG emissions of residential buildings during the construction stages. It is relevant to analyze the system boundaries to make certain that the contribution of all significant factors to the CFP is incorporated. A schematic representation of the system boundaries adopted in the present study is given in Figure 1.

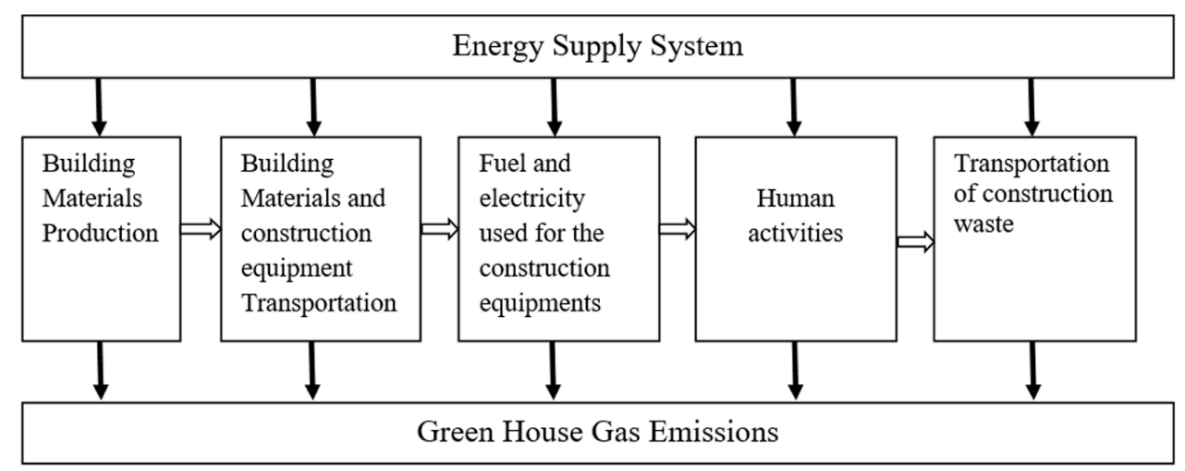

Figure 1. The system boundary of GHG emissions in the construction of residential houses 


\section{Quantification of GHG emissions}

\section{Greenhouse gases emissions from the production of building materials}

The GHG emissions due to the consumption of the building materials can be estimated by Equation 1. The units of GHG emissions are tons of Carbon dioxide equivalent $\left(\mathrm{tCO}_{2 \mathrm{e}}\right)$.

$$
\mathrm{GHG}_{1}=\sum_{\mathrm{i}=1}^{\mathrm{m}} \mathrm{M}_{\mathrm{li}} \times \mathrm{F}_{\mathrm{li}} / 1000
$$

where $\mathrm{GHG}_{1}$ is the total $\mathrm{GHG}$ emissions due to the consumption of all building materials; $\mathrm{m}$ is the number of materials considered; $\mathrm{M}_{1 \mathrm{i}}$ is the quantity (tones) of the $\mathrm{i}^{\mathrm{th}}$ material, and $\mathrm{F}_{1 \mathrm{i}}$ is emission factor of the $\mathrm{i}^{\text {th }}$ material in $\mathrm{tCO}_{2 \mathrm{e}} / \mathrm{kg}$.

The GHG emission factor of building materials considered in the present analysis is given in Table 1.

Table 1. Building materials used in the construction of residential houses. (Data source: Kilbert, 2007; Shams et al., 2011)

\begin{tabular}{|c|c|c|c|c|c|c|}
\hline \multirow[b]{2}{*}{ S.N. } & \multirow[b]{2}{*}{ Material } & \multirow[b]{2}{*}{ Unit } & \multirow{2}{*}{$\begin{array}{l}\text { Emission factor } \\
\left(\mathrm{kgCO}_{2} \mathrm{e} / \mathrm{unit}\right)\end{array}$} & \multicolumn{3}{|c|}{ Consumption } \\
\hline & & & & $\begin{array}{c}\text { Case A } \\
\left(204 \mathbf{~ m}^{2}\right) \\
\end{array}$ & $\begin{array}{c}\text { Case B } \\
\left(150 \mathbf{~ m}^{2}\right) \\
\end{array}$ & $\begin{array}{c}\text { Case C } \\
\left(120 \text { m }^{2}\right) \\
\end{array}$ \\
\hline 1. & Cement & $\mathrm{kg}$ & 0.967 & 31884 & 23913 & 19130.4 \\
\hline 2. & Concrete mixture & $\mathrm{kg}$ & 0.159 & 578271 & 433703.2 & 346962.6 \\
\hline 3. & Stainless Steel bars & $\mathrm{kg}$ & 5.457 & 25220 & 18915 & 15132 \\
\hline 4. & Granite & $\mathrm{kg}$ & 0.04 & 74 & 55.5 & 44.4 \\
\hline 5. & Marble & $\mathrm{kg}$ & 0.436 & 422.5 & 318.8 & 255 \\
\hline 6. & Bricks & $\mathrm{kg}$ & 0.327 & 216075 & 162056 & 129645 \\
\hline 7. & Glass & $\mathrm{kg}$ & 1.735 & 1286 & 964.5 & 771.6 \\
\hline 8. & LPG (on site) & $\mathrm{kg}$ & 3.27 & 65 & 48.75 & 39 \\
\hline 9. & PVC pipes & $\mathrm{kg}$ & 3.23 & 148 & 111 & 88.8 \\
\hline 10. & Aluminum & $\mathrm{kg}$ & 0.622 & & 134 & \\
\hline 11. & Diesel & $\mathrm{kg}$ & 3.17 & 1145 & 855 & 683 \\
\hline 12. & Electricity & $\mathrm{kWh}$ & 0.7898 & 995 & 647 & 591 \\
\hline 13. & Cooking oil (on site use) & $\mathrm{kg}$ & 3.07 & 72 & 54 & 43 \\
\hline 14. & Copper pipes & $\mathrm{Kg}$ & 3.02 & 38 & 28.5 & 22.8 \\
\hline 15 . & Plastic pipes & $\mathrm{m}$ & 0.40 & 140 & 105 & 84 \\
\hline 16. & Electric wires & $\mathrm{kg}$ & 2.84 & 212 & 159 & 127.2 \\
\hline 17. & Lighting fixtures & Set & 35.65 & 32 & 24 & 19.2 \\
\hline 18. & Tiles (floor and wall) & $\mathrm{m}^{2}$ & 18.33 & 535 & 401 & 321 \\
\hline 19. & Plywood & $\mathrm{kg}$ & 0.61 & 210 & 157.5 & 126 \\
\hline 20. & Plaster board & Sheet & 11.35 & 28 & 21 & 16 \\
\hline 21. & Ceramic (wall care putty) & $\mathrm{kg}$ & 0.78 & 2500 & 1875 & 1500 \\
\hline 22. & Welding rod & $\mathrm{kg}$ & 20.5 & 23 & 17 & 14 \\
\hline 23. & Timber plates & $\mathrm{m}^{3}$ & 583 & 52 & 39 & 31.2 \\
\hline 24. & Mosaic & $\mathrm{kg}$ & 0.238 & 708 & 531 & 424.8 \\
\hline 25. & Polyurethane & $\mathrm{kg}$ & 4.31 & 61 & 46 & 36.8 \\
\hline 26. & Perlite & $\mathrm{kg}$ & 0.995 & 174 & 131 & 104.8 \\
\hline 27. & Gravel & $\mathrm{kg}$ & 0.00241 & 26485 & 19864 & 15891.2 \\
\hline 28. & Alcohol & $\mathrm{kg}$ & 0.828 & 48 & 36.5 & 29.2 \\
\hline 29. & Fugitive discharge & $\mathrm{kgBOD}$ & 0.03 & 112 & 84 & 67.2 \\
\hline 30. & Water & Liter & 0.42 & 21768 & 16295 & 12905 \\
\hline
\end{tabular}


Emissions from the transportation of construction equipment and materials

GHG emissions from fuel combustion during the transportation of construction equipment and materials and (in $\mathrm{tCO}_{2 \mathrm{e}}$ ) are calculated by Equation 2.

$$
\mathrm{GHG}_{2}=\sum_{\mathrm{i}=1}^{\mathrm{n}} \mathrm{M}_{2 \mathrm{i}} *\left(\mathrm{D}_{\mathrm{il}} * \mathrm{f}_{2}+\mathrm{D}_{\mathrm{is}} * \mathrm{f}_{3}\right) / 1000
$$

Where $\mathrm{n}$ represents the number of building materials and construction equipment transported to the construction site. $\mathrm{M}_{2 \mathrm{i}}$ is the amount of the $\mathrm{i}^{\text {th }}$ building material or weight of construction equipment in tones. $D_{i l}$ is the transportation distance of the $i^{\text {th }}$ material or equipment by land $(\mathrm{km})$. $\mathrm{D}_{\mathrm{is}}$ is the transportation distance of $\mathrm{i}^{\text {th }}$ material or equipment by sea $(\mathrm{km}) . \mathrm{f}_{1}$ and $\mathrm{f}_{2}$ are emission factors for land and sea transportation, respectively (Yan et al., 2010). The transportation distances of different materials and equipment are obtained from Google maps.

Emissions from the construction equipment due to the consumption of fuel and electricity

Scientific research has discovered that the fuel consumed by the construction equipment viz. dozer, concrete mixture, channel, and angle type tower hoist, etc. results in the emission of different quantities of $\mathrm{N}_{2} \mathrm{O}$ and $\mathrm{CH}_{4}$, categorized as off-road construction (Eggleston et al., 2006). GHG emission from fuels consumptions of the construction equipment can be calculated (in $\mathrm{tCO}_{2 \mathrm{e}}$ ) by Equation 3.

$$
(\mathrm{GHG})_{3}=\sum_{k=1}^{n_{3}} \mathrm{FC}_{\mathrm{k}} \times \mathrm{f}_{3 k} / 1000
$$

Where $\mathrm{GHG}_{3}$ is the total $\mathrm{GHG}$ emission from fuel consumptions by different construction equipment; $\mathrm{n}_{3}$ is the types of fuels (number) used by different construction equipment viz. diesel, LPG, gasoline, etc., $\mathrm{FC}_{\mathrm{k}}$ is the quantity (liters) of the $\mathrm{k}^{\text {th }}$ fuel used by the construction equipment; $\mathrm{F}_{3 \mathrm{k}}$ is the emission factor of the $\mathrm{k}^{\text {th }}$ fuel $\left(\mathrm{kgCO}_{2} \mathrm{e} / \mathrm{L}\right)$.

The emission factor of the $\mathrm{k}^{\text {th }}$ fuel is calculated by Equation 4 .

$$
\mathrm{F}_{3 \mathrm{k}}=\mathrm{F}_{\mathrm{CO} 2}+\mathrm{F}_{\mathrm{CH} 4} \times \mathrm{GWP}_{\mathrm{CH} 4}+\mathrm{F}_{\mathrm{N} 2 \mathrm{O}} \times \mathrm{GWP}_{\mathrm{N} 2 \mathrm{O}}
$$

Where $\mathrm{F}_{\mathrm{CO} 2}, \mathrm{~F}_{\mathrm{CH} 4}$, and $\mathrm{F}_{\mathrm{N} 2 \mathrm{O}}$ is the emission factor of $\mathrm{CO}_{2}, \mathrm{CH}_{4}$, and $\mathrm{N}_{2} \mathrm{O}$, respectively for fuel ' $\mathrm{k}$ '. GWP $\mathrm{CH}_{4}$ and $\mathrm{GWP}_{\mathrm{N} 2 \mathrm{O}}$ are the global warming potentials of $\mathrm{CH}_{4}$ and $\mathrm{N}_{2} \mathrm{O}$, respectively. In India, the on-site construction equipment is either run on diesel or by electricity, so the emission factor and GWP of diesel are given in Table 2 (Yan et al., 2010).

Table 2. Emission factor and GWP of diesel fuel

\begin{tabular}{c|c|c}
\hline Gases & Emission factor $\left(\mathbf{k g C O} \mathbf{C O}_{\mathbf{2}} \mathbf{e} \mathbf{k g}\right)$ & $\mathbf{G W P}$ \\
\hline $\mathrm{CO}_{2}$ & 2.6140 & 1 \\
$\mathrm{CH}_{4}$ & 0.0239 & 21 \\
$\mathrm{~N}_{2} \mathrm{O}$ & 0.0074 & 310 \\
\hline
\end{tabular}


GHG Emissions from electrical energy use for construction equipment like; vibratory plate compactor, sand screening machine, etc., can be calculated by Equation 5.

$$
\mathrm{GHG}_{4}=\mathrm{E} * \mathrm{f}_{5} / 1000
$$

Where $\mathrm{GHG}_{4}$ is the total emission of $\mathrm{GHG}\left(\mathrm{tCO}_{2 \mathrm{e}}\right)$ due to the electricity consumed by the construction equipment, $\mathrm{E}$ is the amount of electric power consumed by the construction equipment during the construction period in $\mathrm{kWh}$. The electricity was supplied by the state electricity board. $f_{5}$ is the emission factor for electricity in India. Its default value is $0.93 \mathrm{~kg} / \mathrm{kWh}$. Table 3 shows the emission factor of electricity in India from 2008 to 2012 ( $\mathrm{tCO}_{2 \mathrm{e}} / \mathrm{MWh}$ ) (User Guide Version 8.0, 2013).

Table 3. The emission factor of electricity in India from 2008 to 2012

\begin{tabular}{c|c|c|c|c|c}
\hline Grid & $\mathbf{2 0 1 2}$ & $\mathbf{2 0 1 1}$ & $\mathbf{2 0 1 0}$ & $\mathbf{2 0 0 9}$ & $\mathbf{2 0 0 8}$ \\
\hline Southern grid & 0.91 & 0.84 & 0.85 & 0.9 & 0.85 \\
North Eastern grid & 0.94 & 0.91 & 0.9 & 0.84 & 0.8 \\
Pan India & 0.93 & 0.9 & 0.88 & 0.85 & 0.81 \\
\hline
\end{tabular}

\section{GHG emissions from human activities}

GHG emissions from human activities include electricity use for processing fresh water and sewage and, consumption of liquefied petroleum gas (LPG) for on-site cooking. Following equations are used to calculate the GHG emissions by these two human activities.

$$
\begin{aligned}
& \mathrm{GHG}_{6}=\mathrm{W}_{\mathrm{W}} * \mathrm{f}_{6} / 1000 \\
& \mathrm{GHG}_{7}=\mathrm{W}_{\mathrm{G}} * \mathrm{f}_{7} / 1000
\end{aligned}
$$

Where $\mathrm{GHG}_{6}$ represent the emissions $\left(\mathrm{tCO}_{2 \mathrm{e}}\right)$ due to the consumption of electric power for processing the fresh and sewage water. $\mathrm{W}_{\mathrm{W}}$ is the quantity of the water used $\left(\mathrm{m}^{3}\right), \mathrm{f}_{6}$ is the emission factor of electricity used in handing out fresh and sewage water $\left(\mathrm{kgCO}_{2 \mathrm{e}} / \mathrm{m}^{3}\right) . \mathrm{GHG}_{7}$ is the $\mathrm{GHG}$ emission due to $\mathrm{LPG}$ used for on-site cooking $\left(\mathrm{tCO}_{2 \mathrm{e}}\right)$, $\mathrm{W}_{\mathrm{G}}$ is the quantity of $\mathrm{LPG}$ used $\left(\mathrm{m}^{3}\right)$ and, $\mathrm{f}_{7}$ is the emission factor for LPG $\left(\mathrm{kgCO}_{2 \mathrm{e}} / \mathrm{m}^{3}\right)$.

\section{Emissions from the transportation of construction waste}

The emissions from combustion of fuel consumed by vehicles used for disposal of construction waste can be estimated by Equation 8.

$$
\mathrm{GHG}_{8}=\mathrm{W}_{\mathrm{S}} * \mathrm{D} * \mathrm{f}_{8} / 1000
$$

Where $\mathrm{W}_{\mathrm{S}}$ is the amount of construction waste (tones), $\mathrm{D}$ is the distance traveled by disposal vehicles for transporting the waste to dumpsite $(\mathrm{km})$, and $\mathrm{f}_{8}$ is the emission factor of the fuel (diesel) used in transportation vehicles $\left(\mathrm{kgCO}_{2 \mathrm{e}} / \mathrm{ton}-\mathrm{km}\right)$. The emission factor for diesel is $3.17 \mathrm{kgCO}_{2 \mathrm{e}} / \mathrm{kg}$ (Hong et al., 2015). 


\section{Estimation of total emissions}

The aggregate emissions during different construction phases of the residential buildings can be calculated by Equation 9 .

$$
\mathrm{GHG}_{\text {Total }}=\sum_{k=1}^{8} C H G \kappa
$$

\section{Case studies of residential buildings}

The present research work has been carried out on real construction projects: three residential houses located in Moradabad district of Uttar Pradesh, India. The land areas are $120 \mathrm{~m}^{2}, 150 \mathrm{~m}^{2}$, and $204 \mathrm{~m}^{2}$. Figure 2 represents the layout and floor plan of the residential houses. The residential buildings under study represent typical middle-class society with independent houses or floors, common in non-metropolitan cities in India like Moradabad.

The description of three residential houses is presented in Table 4 and the materials used for construction are presented in Table 1. The materials include those used in foundation, civil structure, finishing, landscape architecture, and engineering materials.

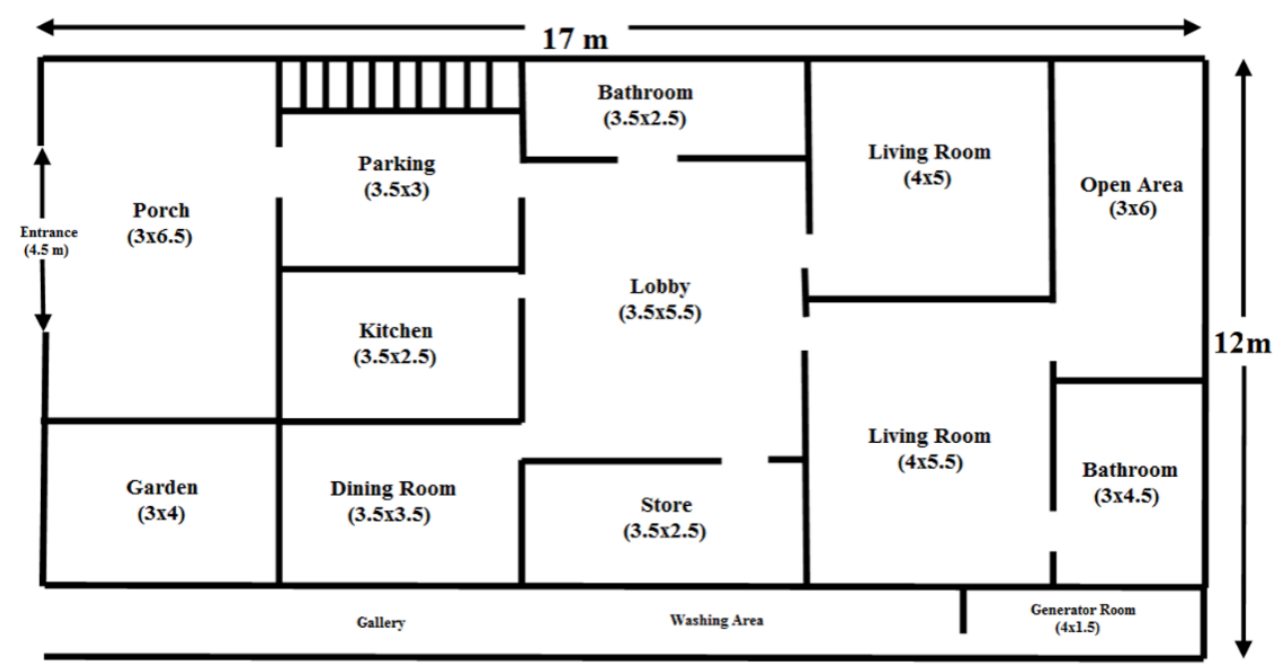

(a)

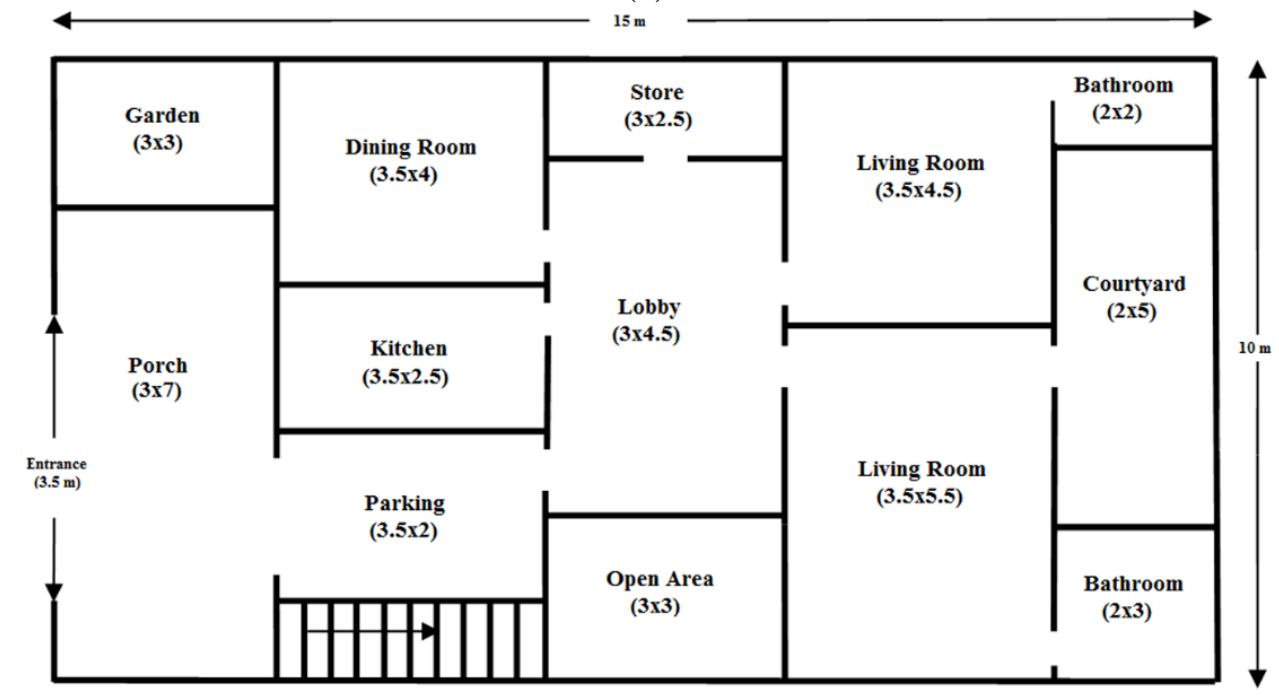

(b) 


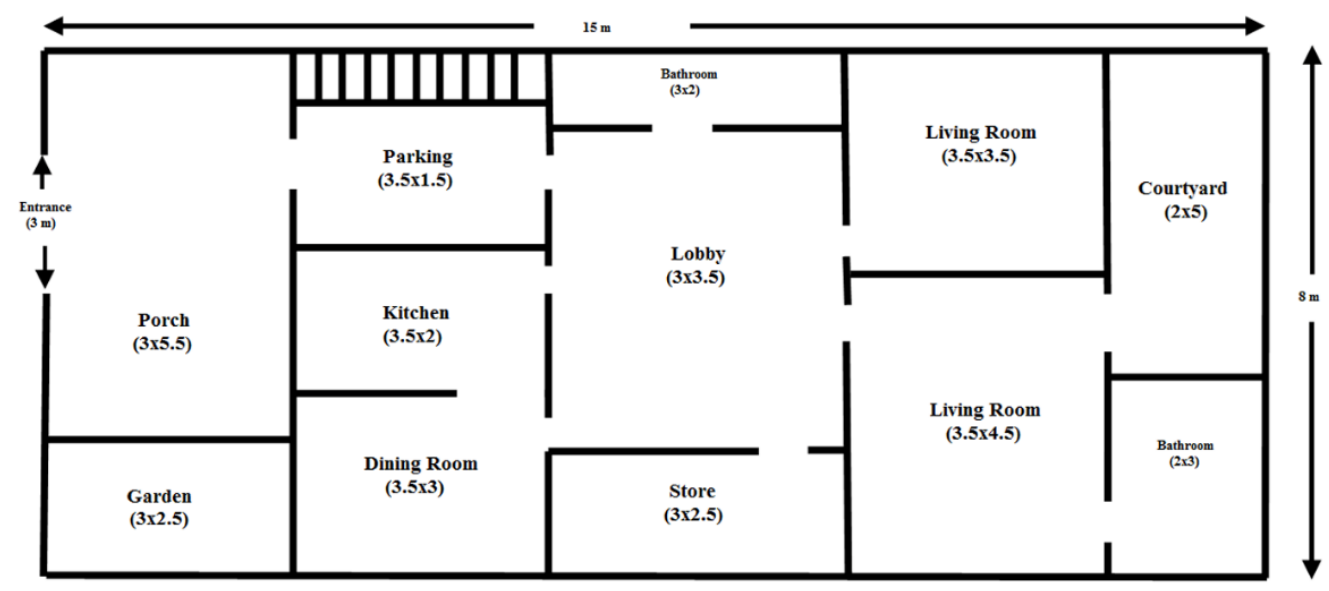

(c)

Figure 2. Floor plan of the three residential buildings with area and GPS coordinates (given in brackets); (a) $204 \mathrm{~m}^{2}\left(28.865838^{\circ} \mathrm{N}, 78.753071^{\circ} \mathrm{E}\right)$; (b) $150 \mathrm{~m}^{2}\left(28.866891^{\circ} \mathrm{N}, 78.750128^{\circ} \mathrm{E}\right)$ and; (c) $120 \mathrm{~m}^{2}\left(28.869725^{\circ} \mathrm{N}, 78.752629^{\circ} \mathrm{E}\right)$

Table 4. Description of three residential houses under study

\begin{tabular}{c|c|c|c|c|c|c|c|c}
\hline Building & $\begin{array}{c}\text { Land area } \\
\mathbf{m}^{2}\end{array}$ & $\begin{array}{c}\text { Number } \\
\text { of floors }\end{array}$ & $\begin{array}{c}\text { Covered area } \\
\text { (ground floor) }\end{array}$ & $\begin{array}{c}\text { Covered area } \\
\text { (first floor) }\end{array}$ & Construction period & $\begin{array}{c}\text { Height of } \\
\text { ceiling }\end{array}$ & Structure & $\begin{array}{c}\text { Concrete } \\
\text { strength }\end{array}$ \\
\hline Case A & 204 & 02 & 144.5 & 110.5 & 25 months and 12 days & $3.35 \mathrm{~m}$ & $\begin{array}{c}\text { Reinforced } \\
\text { concrete }\end{array}$ & $22 \mathrm{MPa}$ \\
\hline Case B & 150 & 02 & 108.2 & 82.8 & 22 months and 15 days & $3.35 \mathrm{~m}$ & $\begin{array}{c}\text { Reinforced } \\
\text { concrete }\end{array}$ & $22 \mathrm{MPa}$ \\
\hline Case C & 120 & 02 & 86.4 & 66.4 & 21 months and 22 days & $3.35 \mathrm{~m}$ & $\begin{array}{c}\text { Reinforced } \\
\text { concrete }\end{array}$ & $22 \mathrm{MPa}$ \\
\hline
\end{tabular}

\section{Results and discussion}

The GHG emissions during the construction of each house have been calculated using Equations $1-8$ by substituting the value of appropriate emission factor and the average emission percent due to the factors included in the study is represented in Figure 3.

From Figure 3 we can see that the production of building materials account for $74 \%$ of the aggregate GHG emissions, $12 \%$ of the aggregate emissions are from transportation of building material and construction equipment, $10 \%$ from fuel and electricity used for construction equipment, $2 \%$ from human activities, and $2 \%$ are from transportation of construction waste. It is observed that besides the massive emission contribution of the productions of building material and their transportation, human activities also contribute $2 \%$ of overall emissions during the construction of the residential building. This requires adequate attention of the researchers. The average GHG emission of the three residential buildings was estimated to be around 0.784 $\mathrm{tCO}_{2 \mathrm{e}} / \mathrm{m}^{2}$.

Figure 4 indicates GHG emissions from primary building materials. It can be seen that GHG emissions from steel, cement, bricks, and concrete mixture were $0.54 \mathrm{tCO}_{2 \mathrm{e}} / \mathrm{m}^{2}$ for residential buildings and account for about $68.87 \%$ of the total emissions. 


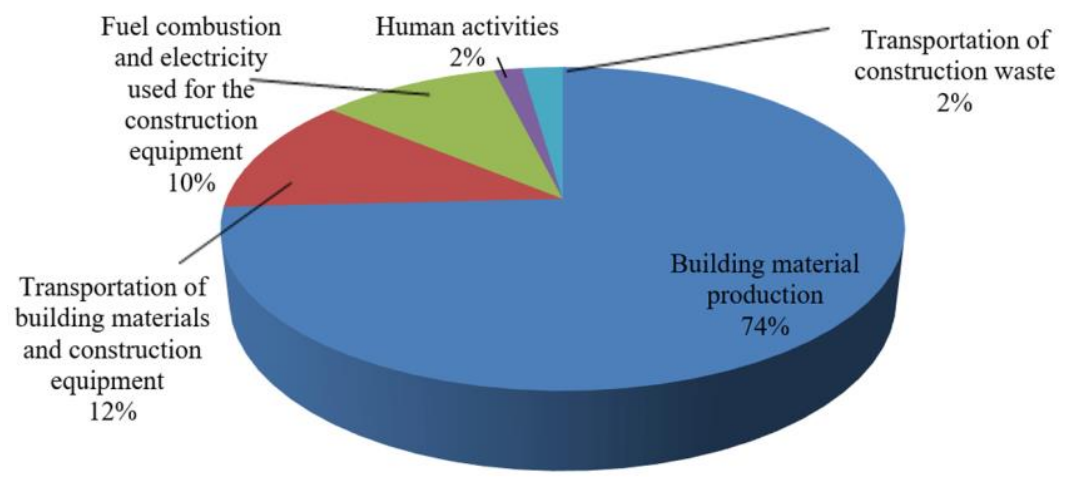

Figure 3. Distribution of average of the aggregate GHG emissions, in three houses

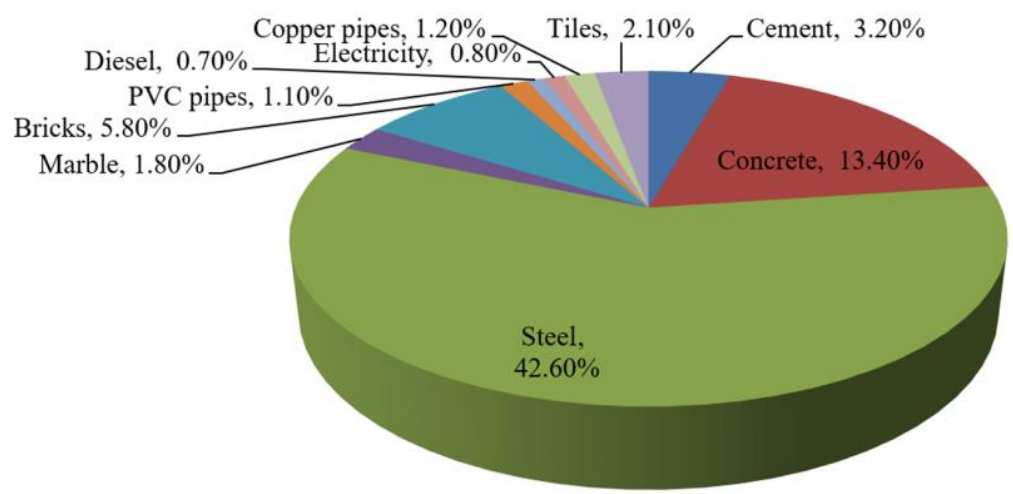

Figure 4. GHG emissions of primary building materials

The GHG emissions from steel and cement, the most important construction materials, was approximately $0.349 \mathrm{tCO}_{2 \mathrm{e}} / \mathrm{m}^{2}$ and $0.025 \mathrm{tCO}_{2 \mathrm{e}} / \mathrm{m}^{2}$ respectively. Other materials like PVC pipes, copper pipes, tiles, marble, diesel, aluminum, plywood, mosaic, etc. have a relatively small contribution.

The consumption of electricity, water and fuel (diesel) in the three residential building are given in Table 5 month wise. The blank column indicates no consumption due to the completion of construction of the building. The GHG emissions due to the consumption of electricity, water and fuel during the construction stages were estimated from this data.

In the Moradabad district of northern India, nearly 3000 residential houses were constructed in the year 2012-13, with a covered area of approximately $390,000 \mathrm{~m}^{2}$ (discussion with the town planner, 2013), at this pace of construction of new residential buildings, it is estimated that total GHG emissions may be about $305,760 \mathrm{tCO}_{2 \mathrm{e}}$ annually.

In order to reduce the emissions due to the construction activities, the recycled building materials along with the environmentally friendly construction practices are recommended to minimize the harm to the environment. Prefabricated building materials and components should be preferred to recover the environmental losses due to GHG emissions. Published research shows that adoption of prefabrication technology during the construction stage add appreciably in the sustainable development of the construction sector (Hong et al., 2015; Aye et al., 2012; Mao et al., 2013; Pons et al., 
2011). The comparative values of GHG emissions estimated using Equations 1-9 are given in Table 6. Based on the analysis of results, the major contributors to GHG emissions have been selected. The consumption of materials is directly related to the emissions and the covered area.

Table 5. Diesel, electricity, and water used in the construction of residential houses

\begin{tabular}{c|c|c|c|c|c|c|c|c|c}
\hline \multirow{2}{*}{\begin{tabular}{c} 
Month \\
\cline { 2 - 9 }
\end{tabular}} & $\begin{array}{c}\text { Ciesel } \\
(\mathbf{k g})\end{array}$ & $\begin{array}{c}\text { Electricity } \\
(\mathbf{k W h})\end{array}$ & $\begin{array}{c}\text { Water } \\
(\mathbf{L i t e r})\end{array}$ & $\begin{array}{c}\text { Diesel } \\
(\mathbf{k g})\end{array}$ & $\begin{array}{c}\text { Electricity } \\
(\mathbf{k W h})\end{array}$ & $\begin{array}{c}\text { Water } \\
(\mathbf{L i t e r})\end{array}$ & $\begin{array}{c}\text { Diesel } \\
(\mathbf{k g})\end{array}$ & $\begin{array}{c}\text { Electricity } \\
(\mathbf{k W h})\end{array}$ & $\begin{array}{c}\text { Water } \\
(\mathbf{L i t e r})\end{array}$ \\
\hline 01 & 29 & 32 & 485 & 22 & 24 & 364 & 17 & 19 & 291 \\
02 & 27 & 18 & 1003 & 20 & 13 & 752 & 16 & 11 & 602 \\
03 & 29 & 1 & 728 & 22 & 1 & 546 & 17 & 1 & 437 \\
04 & 30 & 8 & 874 & 23 & 6 & 655 & 18 & 5 & 524 \\
05 & 30 & 4 & 644 & 23 & 3 & 483 & 18 & 2 & 386 \\
06 & 46 & 37 & 694 & 35 & 28 & 520 & 28 & 22 & 416 \\
07 & 49 & 17 & 759 & 37 & 13 & 569 & 29 & 10 & 455 \\
08 & 66 & 28 & 1014 & 49 & 21 & 760 & 39 & 17 & 608 \\
09 & 73 & 29 & 1135 & 54 & 22 & 851 & 44 & 18 & 681 \\
10 & 105 & 38 & 1285 & 79 & 29 & 964 & 63 & 23 & 771 \\
11 & 139 & 37 & 2468 & 104 & 27 & 1851 & 84 & 22 & 1481 \\
12 & 119 & 58 & 2191 & 89 & 43 & 1643 & 71 & 35 & 1315 \\
13 & 101 & 21 & 2640 & 76 & 16 & 1980 & 61 & 13 & 1584 \\
15 & 213 & 46 & 1879 & 160 & 35 & 1409 & 128 & 28 & 1127 \\
16 & 78 & 26 & 1638 & 58 & 20 & 1228 & 47 & 16 & 983 \\
17 & 6 & 102 & 1571 & 4 & 76 & 1178 & 3 & 61 & 943 \\
18 & 5 & 97 & 602 & -- & 73 & 408 & -- & 58 & 301 \\
19 & -- & 84 & 102 & -- & 63 & 96 & -- & 51 & -- \\
20 & -- & 97 & 56 & -- & 73 & 38 & -- & 58 & -- \\
21 & -- & 101 & -- & -- & 61 & -- & -- & 121 & -- \\
22 & -- & 87 & -- & -- & -- & -- & -- & -- & -- \\
23 & -- & 27 & -- & -- & -- & -- & -- & -- & -- \\
\hline
\end{tabular}

Table 6. Comparative GHG emissions from major building materials in three houses

\begin{tabular}{c|c|c|c}
\hline Case & A & B & C \\
\hline Plot area $\left[\mathrm{m}^{2}\right]$ & 204 & 150 & 120 \\
Covered area $\left[\mathrm{m}^{2}\right]$ & 144.5 & 108.2 & 86.4 \\
\hline \multicolumn{2}{c|}{$\mathrm{CO}_{2}$ emissions $\left[\mathrm{tCO}_{2 \mathrm{e}}\right]$} & \multicolumn{1}{|c}{ due to major construction materials } \\
\hline Cement & 3.6125 & 2.705 & 2.16 \\
Steel & 50.4305 & 37.7618 & 30.1536 \\
Bricks & 6.5025 & 4.869 & 3.888 \\
Concrete & 15.1725 & 11.361 & 9.072 \\
Tiles & 2.312 & 1.7312 & 1.3824 \\
Marble & 2.023 & 1.5148 & 1.2096 \\
PVC & 1.2427 & 0.93052 & 0.74304 \\
Copper pipes & 1.3583 & 1.01708 & 0.81216 \\
Electricity & 0.8959 & 0.67084 & 0.53568 \\
Diesel & 0.7803 & 0.58428 & 0.46656 \\
\hline
\end{tabular}




\section{Comparative and critical discussion}

Based on the study and in correlation with the published research on GHG emissions in different parts of the world, it is deduced that the building construction activities need restructuring to consider the impact of the construction activities and building materials on the environment. It is recommended that the management, contractors, labor and, other stakeholders ought to refer the following guidelines to lower the GHG emissions during the construction stage of buildings.

1. Choose construction sites having low ecological and agricultural significance without any interference with biodiversity.

2. Every construction project should set goals to minimize GHG emissions and watch the performance. GHG emissions should be an important consideration in the design process.

3. Include materials that are more competent and less harmful to the environment.

4. Incorporate features like green roofs and walls and use local species in plantation and landscaping.

5. Saving energy at every stage of the construction process should be a top priority.

6. Poor management and tardy design modifications are the main contributors to waste. Therefore, avoid late modifications to design and intend all work from the commencement of the construction process in order to minimize waste.

7. Strike down over-ordering and facilitate the recycling of waste. Prefer way outs that produce a lesser amount of waste and design material goods that can be dismantled and reused.

8. Make use of materials that can be recycled. Use minimum packing to shield the product. Prefer reuses and avoid landfill.

9. Put the target to minimize water consumption and evaluate progress throughout the construction phase. Use machines and equipment that save water, inspire everyone to detect and report water leaks, and fix them at the earliest possible.

10. Proper project management with time-activity scheduling, deriving benefits from weather and climate, minimize curing and encourage use to solar energy and daylight.

\section{Conclusions}

Three residential buildings were identified in Moradabad region of northern India and their construction stages were carefully monitored over a period of two years from 2010-11 to 2012-13 until the buildings were completed. The authors 1, 3 and 4, owned the three buildings, identified as the research subject and so the research and results are $100 \%$ authentic and established. The consumption of the construction material, fuel and, electric power was maintained on a day-to-day basis. The equations used to estimate the GHG emissions at a different stage of construction and the aggregate emissions under the framework of the study were developed by the authors. The main deductions from the study highlight that the emissions from building material production account for $74 \%$ of the aggregate emissions. Among the construction materials steel, bricks, cement and, concrete together account for about $66 \%$ of the aggregate emissions. On-site human activities during the construction phases, which is yet to be published in the research domain, also contribute to the GHG emissions. The deductions of this study are beneficial for the sustainable design and construction management of the residential 
buildings in India and may be used as a reference for developing the strategy and policy to minimize GHG emissions in the building construction industry in any part of the world. The authors are presently working on the life cycle assessment of GHG emissions of the residential buildings taken as research subjects in this study. A life cycle approach is aimed to be developed to investigate the GHG consequences of orthodox as well as low energy forms of residential building construction in India. The authors also aim at extending their work in estimating the life cycle carbon emissions of the residential buildings and further extending the scope of the study to the Kingdom of Saudi Arabia.

Acknowledgments. Authors thankfully acknowledge the funding and support provided by Scientific Research Deanship, King Khalid University, Abha-Asir, Kingdom of Saudi Arabia, with project grant number G.R.P-260-39 to complete the research work.

\section{REFERENCES}

[1] Akten, M., Akyol, A. (2018): Determination of environmental perceptions and awareness towards reducing carbon footprint. - Applied Ecology and Environmental Research 16(4): 5249-5267. DOI: http://dx.doi.org/10.15666/aeer/1604_52495267.

[2] Arena, A. P., Rosa, C. de (2003): Life cycle assessment of energy and environmental implications of the implementation of conservation technologies in school buildings in Mendoza - Argentina. - Building and Environment 38:359-368. DOI: https://doi.org/10.1016/S0360-1323(02)00056-2.

[3] Asif, M. A, Muneer, T, Kelley, R. (2007): Life cycle assessment: A case study of a dwelling home in Scotland. - Building and Environment 42:1391-1394. DOI: 10.1016/j.buildenv.2005.11.023.

[4] Aye, L., Ngo, T., Crawford, R. H., Gammampila, R., Mendis, P. (2012): Life cycle greenhouse gas emissions and energy analysis of prefabricated reusable building modules. - Energy and Buildings 47:159-168. DOI: 10.1016/j.enbuild.2011.11.049.

[5] Blasing, T. J. (2014): Recent Greenhouse Gas Concentrations. - Carbon Dioxide Information Analysis Center. DOI:10.3334/CDIAC/atg.032.

[6] Cui, C., Wang, Z., Bin, G. (2019): Life-cycle $\mathrm{CO}_{2}$ emissions and their driving factors in construction sector in China. - Chinese Geographical Science 29: 293-305. DOI.org/10.1007/s11769-019-1029-z.

[7] Chou, J., Yeh, K. (2015): Life cycle carbon dioxide emissions simulation and environmental cost analysis for building construction. - Journal of Cleaner Production 101:137-147. DOI: 10.1016/j.jclepro.2015.04.001.

[8] Devi, P., Palaniappan, S. (2014): A case study on life cycle energy use of residential building in Southern India. - Energy and Buildings 80: 247-259. DOI: http://dx.doi.org/10.1016/j.enbuild.2014.05.034.

[9] Dimoudi, A., Tompa, C. (2008): Energy and environmental indicators related to construction of office buildings. - Resources, Conservation and Recycling 53: 86-95. DOI: 10.1016/j.resconrec.2008.09.008.

[10] Discussion with the Town Planner (2013): Moradabad Development Authority. - Govt. of Uttar Pradesh, India on 09.12.2013.

[11] Doğan, H. G. (2018): Nexus of agriculture, GDP, population and climate change : case of some Eurasian countries and Turkey. - Applied Ecology and Environmental Research 16(5): 6963-6976. DOI: http://dx.doi.org/10.15666/aeer/1605_69636976. 
[12] Eggleston, H. S., Buendia, L., Miwa, K., Ngara, T., Tanabe, K. (2006): IPCC Guidelines for National Greenhouse Gas Inventories, Prepared by the National Greenhouse Gas Inventories Programme. - IGES, Japan.

[13] Hong, J., Qiping, G., Feng, Y., Lau, W. S., Mao, C. (2015): Greenhouse gas emissions during the construction phase of a building: a case study in China. - Journal of Cleaner production 103:249-259. DOI: 10.1016/j.jclepro.2014.11.023.

[14] Hossain, U., Ng, S. T. (2019): Influence of waste materials on buildings' life cycle environmental impacts: adopting resource recovery principle. - Resources, Conservation \& Recycling 142: 10-23. DOI: 10.1016/j.resconrec.2018.11.010.

[15] International Energy Agency (IEA) (2015): World Energy Outlook Special Report: Energy and Climate Change. - IEA, Paris.

[16] Kilbert, C. J. (2007): Sustainable Construction: Green Building Design and Delivery. Wiley, Hoboken, NJ.

[17] Lai, J. H. K. (2015): Carbon footprints of hotels: analysis of three archetypes in Hong Kong. - Sustainable Cities and Society 14: 334-341. DOI: 10.1016/j.scs.2013.09.005.

[18] Li, Y. L., Han, M. Y., Liu, S. Y., Chen, G. Q. (2019): Energy consumption and greenhouse gas emissions by buildings: A multi- scale perspective. - Building and Environment 151:240-250. DOI: 10.1016/j.buildenv.2018.11.003.

[19] Lin, B., Liu, H. (2015): $\mathrm{CO}_{2}$ emissions of China's commercial and residential buildings: Evidence and reduction policy. - Building and Environment 92: 418-431. DOI: 10.1016/j.buildenv.2015.05.020.

[20] Mao, C., Shen, Q., Shen, L., Tang, L. (2013): Comparative study of greenhouse gas emissions between off-site prefabrication and conventional construction methods: Two case studies of residential projects. - Energy and Buildings 66:165-176. DOI: 10.1016/j.enbuild.2013.07.033.

[21] Marsono, A. K. B., Balasbaneh, A. T. (2015): Combinations of building construction material for residential building for the global warming mitigation for Malaysia. Construction and Building Materials 85: 100-108. DOI: http://dx.doi.org/10.1016/j.conbuildmat.2015.03.083.

[22] Mora, C., Frazier, A. G., Longman, R. J., Dacks, R. S., Walton, M. M., Tong, E. J., Sanchez, J. J., Kaiser, L. R., Stender, Y. O., Anderson, J. M., Ambrosino, C. M., Fernandez-silva, I., Giuseffi, L. M., Giambelluca, T. W. (2013): The projected timing of climate departure from recent variability. - Nature 502:183-187. DOI: 10.1038/nature12540.

[23] Moschetti, R., Brattebø, H., Sparrevik, M. (2019): Energy \& Buildings Exploring the pathway from zero-energy to zero-emission building solutions: a case study of a Norwegian office building. - Energy and Buildings 188-189:84-97. DOI: 10.1016/j.enbuild.2019.01.047.

[24] Nation Master Statistic (2013): $\mathrm{CO}_{2}$ Emission by Country. - www.nationmaster.com.

[25] Onat, N. C., Egilmez, G., Tataria, O. (2014): Towards greening the U.S. residential building stock: a system dynamics approach. - Building and Environment 78: 68-80. DOI: http://dx.doi.org/10.1016/j.buildenv.2014.03.030.

[26] Pons, O., Wadel, G. (2011): Environmental impacts of prefabricated school buildings in Catalonia. - Habitat International 35:553-563. DOI: 10.1016/j.habitatint.2011.03.005.

[27] Shams, S., Mahmud, K., Al-Amin, M. (2011): A comparative analysis of building materials for sustainable construction with emphasis on $\mathrm{CO}_{2}$ reduction. - Int. J. Environment and Sustainable Development 10: 364-374. DOI: 10.1504/IJESD.2011.047767.

[28] Sharma, A., Shree, V., Nautiyal, H. (2012): Life cycle environmental assessment of an educational building in Northern India: a case study. - Sustainable Cities and Society 4:22-28. DOI: 10.1016/j.scs.2012.03.002.

[29] Statics Times (2015): Sector-wise contribution of GDP of India. http://statisticstimes.com/economy/sectorwise-gdp-contribution-of-india.php. 
[30] Suzuki, M., Oka, T., Okada, K. (1995): The estimation of energy consumption and $\mathrm{CO}_{2}$ emission due to housing construction in Japan. - Energy and Buildings 22: 165-169. DOI: https://doi.org/10.1016/0378-7788(95)00914-J.

[31] UNEP (2009): Buildings and Climate Change Summary for Decision-Makers. http://www.unep.org/sbci/pdfs/SBCI-BCCSummary.pdf.

[32] User Guide, Version 8.0 (2013): $\mathrm{CO}_{2}$ Baseline Database for the Indian Power Sector. Government of India, Ministry of Power, Central Electricity Authority, New Delhi.

[33] Wang, X., Duan, Z., Wu, L., Yang, D. (2015): Estimation of carbon dioxide emission in highway construction: a case study in southwest region of China. - Journal of Cleaner Production 103:705-714. DOI: 10.1016/j.jclepro.2014.10.030.

[34] Wong, P. S. P., Holdsworth, S., Crameri, L., Lindsay, A. (2019): Does carbon accounting have an impact on decision-making in building design? - International Journal of Construction Management 19(2): 149-161. DOI: 10.1080/15623599.2017.1401290.

[35] Yan, H., Shen, Q., Fan, L. C. H., Wang, Y., Zhang, L. (2010): Greenhouse gas emissions in building construction: a case study of One Peking in Hong Kong. - Building and Environment 45:949-955. DOI: 10.1016/j.buildenv.2009.09.014.

[36] Yang, C. Y., Wang, H. J., Zhao, S. X., Cui, X. Y., Deng, B., Liu, X. P. (2018): Exaggerated climate warming on the assumption of uniform atmospheric $\mathrm{CO}_{2}$ concentration. - Applied Ecology and Environmental Research 16(4): 3711-3728. DOI: http://dx.doi.org/10.15666/aeer/1604_37113728.

[37] Zheng, D. C., Liu, W. X., Li, X. X., Lin, Z. Y., Jiang, H. (2018): Research on carbon emission diversity from the perspective of urbanization. - Applied Ecology and Environmental Research 16(5): 6643-6654. DOI: http://dx.doi.org/10.15666/aeer/1605_66436654. 